\title{
ANALISIS PENERAPAN TOTAL QUALITY MANAGEMENT (TQM) TERHADAP PENINGKATAN LABA PADA PT. TJCM (Total Quality Management (TQM) Application Analysis to Increased Profit on PT. TJCM)
}

\author{
Mohamad Rizal Nur Irawan \\ Fakultas Ekonomi Universitas Islam Lamongan \\ rizalirawan@unisla.ac.id
}

\begin{abstract}
Abstrak: Salah satu pendekatan yang dapat dilakukan oleh perusahaan bisnis untuk meningkatkan daya saing adalah dengan menerapkan Total Quality Manajemen (TQM). TQM mempunyai dasar pemikiran yang terletak pada hasil kualitas yang baik. Tujuan dalam penelitian ini adalah (1) Untuk mengetahui apakah penerapan Total Quality Manajemen (TQM) berpengaruh signifikan secara parsial terhadap peningkatan laba (Y) pada PT.Trijaya Cipta Makmur Lamongan. (2) Untuk mengetahui apakah penerapan Total Quality Manajemen (TQM) berpengaruh signifikan secara simultan terhadap peningkatan laba (Y) pada PT.Trijaya Cipta Makmur Lamongan. (3) Untuk mengetahui variabel manakah yang berpengaruh paling dominan terhadap peningkatan laba (Y) pada PT.Trijaya Cipta Makmur Lamongan. Penelitian ini dilaksanakan dengan menggunakan metode kuantitatif. Analisis data yang diperoleh dengan kuesioner di uji dengan menggunakan Uji Validitas, Uji Reliabilitas, Uji Asumsi Klasik, Regresi Linier Berganda, Korelasi Berganda, Koefisien Determinasi, Uji t dan Uji F. Hasil analisis menunjukkan bahwa thit $>$ ttab dengan nilai tHit $(X 1)=17,399$, tHit $(X 2)=21,845$, thit $(X 3)=20,819$, tHit $(X 4)=29,484$, tHit $(X 5)=10,297$, dan Fhit $=31,870>\mathrm{Ftab}=2,47$. Berdasarkan bukti-bukti tersebut dapat disimpulkan bahwa (1) Penerapan Total Quality Manajemen (TQM) berpengaruh signifikan secara parsial terhadap peningkatan laba pada PT.Trijaya Cipta Makmur Lamongan. (2) Penerapan Total Quality Manajemen (TQM) berpengaruh signifikan secara simultan terhadap peningkatan laba pada PT.Trijaya Cipta Makmur Lamongan. (3) Variabel kesatuan tujuan (X4) yang berpengaruh paling dominan terhadap peningkatan laba pada PT.Trijaya Cipta Makmur Lamongan karena hasil tHit (X4) lebih besar daripada ke-empat variabel lainnya.
\end{abstract}

Kata kunci : Analisis Data ; Peningkatan Laba ; Total Quality Manajemen (TQM)

\section{PENDAHULUAN}

Perusahaan pasti mempunyai tujuan yang hendak dicapai dalam kegiatannya, yaitu untuk memperoleh laba yang maksimal untuk mencapai tujuan tersebut, maka bagi seorang pemimpin perusahaan di tuntut untuk bekerja keras demi kelangsungan hidup suatu perusahaan, baik untuk masa sekarang maupun untuk masa yang akan datang. Sehingga beberapa perusahaan menerapkan Total Quality Manajemen (TQM) agar dapat meningkatkan laba perusahaan.

Dipietro mendefinisikan Total Quality Management sebagai konsep perbaikan yang dilakukan secara terus menerus, yang melibatkan semua karyawan disetiap level organisasi untuk mencapai kualitas yang exellent dalam semua 
aspek organisasi melalui proses manajemen (Rusdiana, 2014 : 229). Sedangkan Vincent Gazperz (2001 : 5) mendefinisikan Total Quality Management adalah suatu cara meningkatkan performansi secara terus menerus (continuous performance improvement) pada setiap level operasi atau proses, dalam setiap area fungsional dari suatu organisasi, dengan menggunakan sumber daya manusia dan modal yang tersedia, misalnya pada peningkatan laba. Laba adalah jumlah yang berasal dari pengurangan harga pokok produksi, biaya lain dan kerugian dari penghasilan atau penghasilan operasi (Harahap, 2011:112). Oleh karena itu penulis tertarik untuk mengadakan penelitian tentang Analisis Penerapan Total Quality Manajemen (TQM) pada PT. Trijaya Cipta Makmur Lamongan.

Rumusan masalah pada penelitian ini adalah (1) Apakah penerapan Total Quality Manajemen (TQM) berpengaruh yang signifikan secara parsial terhadap peningkatan laba (Y) pada "PT.Trijaya Cipta Makmur Lamongan". (2) Apakah penerapan Total Quality Manajemen (TQM) berpengaruh yang signifikan secara simultan terhadap peningkatan laba (Y) pada "PT.Trijaya Cipta Makmur Lamongan". (3) Variabel manakah yang berpengaruh paling dominan terhadap peningkatan laba (Y) pada "PT.Trijaya Cipta Makmur Lamongan".

Penelitian terdahulu yang dilakukan oleh Eriyundani mahasiswa fakultas ekonomi, manjemen Universitas Hasanuddin Makasar tahun 2013 dengan judul penelitian "Pengaruh Total Quality Management Terhadap Laba Perusahaan Pada PT.Toyota Kalla
Cabang Cokroaminoto Makasar" dan hasil penelitian ini membuktikan bahwa penerapan Total Quality Management berpengaruh positif dan signifikan terhadap laba perusahaan. Sehingga tujuan penelitian yang dilakukan oleh penulis adalah (1) Untuk mengetahui apakah penerapan Total Quality Management (TQM) berpengaruh yang signifikan secara parsial terhadap peningkatan laba (Y) pada "PT.Trijaya Cipta Makmur Lamongan". (2) Untuk mengetahui apakah penerapan Total Quality Manajemen (TQM) berpengaruh yang signifikan secara simultan terhadap peningkatan laba (Y) pada "PT.Trijaya Cipta Makmur Lamongan". (3) Untuk mengetahui variabel manakah yang berpengaruh paling dominan terhadap peningkatan laba (Y) pada "PT.Trijaya Cipta Makmur Lamongan".

\section{METODE PENELITIAN}

Jenis penelitian yang digunakan oleh penulis adalah metode kuantitatif. Analisis data yang diperoleh dengan kuesioner di uji dengan menggunakan Uji Validitas, Uji Reliabilitas, Uji Asumsi Klasik, Regresi Linier Berganda, Korelasi Berganda, Koefisien Determinasi, Uji t dan Uji F. Teknik pengambilan sampel yang digunakan oleh penulis adalah teknik sampling random karena pengambilan anggota sampel dari populasi dilakukan secara acak tanpa memperhatikan strata yang ada dalam populasi itu (Sugiyono, 2012 : 82). Variabel yang diteliti adalah terdiri dari variabel bebas (X) dan variabel terikat (Y). TQM sebagai Variabel Bebas (X) yang meliputi Kerjasama Tim (X1), Perbaikan Sistem Secara Berkesinambungan 
(X2), Pendidikan dan Pelatihan (X3), Kesatuan Tujuan (X4), serta Keterlibatan dan Pemberdayaan Karyawan (X5) dan Peningkatan Laba sebagai Variabel Terikat (Y). Model statistik yang digunakan SPSS 17.0 for windows.

\section{HASIL DAN PEMBAHASAN}

Tabel 1. Rekapitulasi Hasil Uji Validitas

\begin{tabular}{|c|c|c|c|c|c|}
\hline $\mathrm{No}_{0}$ & Tariabel & Indikator & nim & ralu & Keterangan \\
\hline \multirow[t]{2}{*}{1} & \multirow[t]{2}{*}{ Karjaama $\operatorname{Tim}\left(\mathrm{X}_{\mathrm{l}}\right)$} & $\mathrm{X}_{14}$ & 6.657 & 0.1966 & Vellid \\
\hline & & $X_{12}$ & 1 & 0,1966 & Volid \\
\hline \multirow[t]{3}{*}{2} & \multirow{3}{*}{$\begin{array}{l}\text { Pethaiks Sistem Sccua } \\
\text { Bexkeninambugan }\left(\mathrm{X}_{\mathrm{i}}\right)\end{array}$} & $X_{34}$ & 0,701 & 0,1975 & Volido \\
\hline & & $\mathrm{X}_{33}$ & 0,029 & 0,1975 & Valid \\
\hline & & $\mathrm{X}_{39}$ & 1 & 0,1975 & Valid \\
\hline \multirow[t]{4}{*}{3} & \multirow{4}{*}{$\begin{array}{l}\text { Pendidilkan den Pelathan } \\
\left(X_{S}\right)\end{array}$} & $\mathrm{X}_{51}$ & 0,637 & 0,1936 & Vulla \\
\hline & & $\mathrm{X}_{31}$ & 0,695 & 0,1986 & VEllid \\
\hline & & $x_{3 s}$ & 0,657 & 0,1986 & Volld \\
\hline & & $X_{3 A}$ & $\mathrm{~T}$ & 0,1536 & Vellid \\
\hline \multirow[t]{2}{*}{4} & \multirow[t]{2}{*}{ Kesatual Trjuан $\left(\mathrm{X}_{4}\right)$} & $x_{41}$ & 0,23 & 0,1566 & VElld \\
\hline & & $X_{41}$ & 1 & 0,1906 & Velld \\
\hline \multirow[t]{2}{*}{5} & \multirow{2}{*}{ 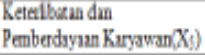 } & $x_{y}$ & 0,696 & 0,1566 & Valid \\
\hline & & $x_{3}$ & T & 0,1966 & Valid \\
\hline \multirow[t]{2}{*}{6} & \multirow[t]{2}{*}{ Peninpksten Labe (Y) } & $Y_{1}$ & 0,742 & 0,1966 & Valid \\
\hline & & $Y_{i}$ & 1 & 0,1966 & Vellid \\
\hline
\end{tabular}

Nilai $r$ tabel diperoleh dari $d f=n-k, n$ adalah jumlah sampel penelitian, sedangkan $k$ adalah jumlah butir pernyataan (indikator) masing-masing kontruk (variabel) yaitu 5 variabel. Perhitungan $r$ tabel $d f=100-2$ adalah untuk variabel kerjasama tim $\left(\mathrm{X}_{1}\right), \quad \mathrm{r}$ tabel $d f=100-3 \quad$ untuk variabel perbaikan sistem secara berkesinambungan $\left(\mathrm{X}_{2}\right), \quad \mathrm{r}$ tabel $d f=100-4$ untuk variabel pendidikan dan pelatihan $\left(\mathrm{X}_{3}\right), \mathrm{r}$ tabel $d f=100-2$ untuk variabel kesatuan tujuan $\left(\mathrm{X}_{4}\right)$, dan $\mathrm{r}$ tabel $d f=100-2 \quad$ untuk variabel keterlibatan dan pemberdayaan karyawan $\left(\mathrm{X}_{5}\right)$, dan $\mathrm{r}$ tabel $d f=100-2 \quad$ untuk variabel peningkatan laba (Y). Jika nilai $r$ hitung lebih besar dari $r$ tabel ( $r$ hitung > $\mathrm{r}$ tabel). Berdasarkan uji validitas untuk kelima variabel bebas (X) dan variabel terikat (Y) diatas diperoleh $r$ hitung $>r$ tabel. Sehingga keseluruhan indikator dari enam variabel tersebut dinyatakan Valid.

Tabel 2. Rekapitulasi Hasil Uji Reliabilitas

\begin{tabular}{|l|c|c|c|}
\hline \multicolumn{1}{|c|}{ Indikator Pernyataan } & Nilai Alpha & Nilai Kritis & Keterangan \\
\hline Kejacama Tim & 0,605 & 0,6 & Reliabel \\
\hline $\begin{array}{l}\text { Perbaikan Sistem Socara } \\
\text { Berkesinambungan }\end{array}$ & 0,627 & 0,6 & Reliabel \\
\hline Pendidikan dan Pelatihan & 0,650 & 0,6 & Reliabel \\
\hline Kesatuan Tujuan & 0,819 & 0,6 & Reliabel \\
\hline $\begin{array}{l}\text { Keterlibatan dan } \\
\text { Pemberdayaan Karyawan }\end{array}$ & 0,746 & 0,6 & Reliabel \\
\hline Peniugkatan Laba & 1,000 & 0,6 & Reliabel \\
\hline
\end{tabular}

Hasil pengujian reliabilitas dengan SPSS metode Alpha Cronbach's diperoleh koefisien alpha Kerjasama Tim $\left(\mathrm{X}_{1}\right)$ sebesar 0,605, Perbaikan Sistem Secara Berkesinambungan $\left(\mathrm{X}_{2}\right)$ sebesar 0,627 , Pendidikan dan Pelatihan $\left(X_{3}\right)$ sebesar 0,650, Kesatuan Tujuan $\left(\mathrm{X}_{4}\right)$ sebesar 0,819, Keterlibatan dan Pemberdayaan Karyawan $\left(\mathrm{X}_{5}\right)$ sebesar 0,746 dan Peningkatan Laba (Y) sebesar 1,000. Koefisien Alpha yang diperoleh dibandingkan dengan nilai kritis, jika lebih besar dari nilai kritis maka instrumen reliabel. Pada taraf $a=0,05$ dan $n=100$ ternyata koefisien Alpha yang diperoleh masing-masing variabel adalah $>0,6$ yang artinya instrument yang digunakan Reliabel.

Tabel 3. Asumsi Klasik

a. Uji Heteroskedastisitas

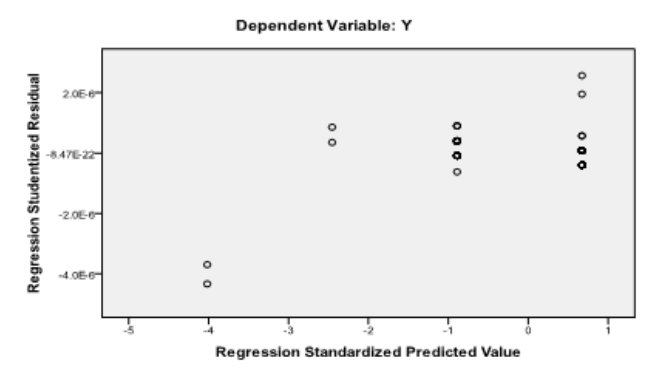

Dari gambar diatas bisa dikatakan bahwa scatter plot tidak mempunyai pola penyebaran yang jelas dan titik tersebut menyebar diatas dan 
dibawah angka 0 pada sumbu $\mathrm{Y}$ sehingga bisa dikatakan tidak terjadi heteroskedastisitas.

\section{b. Uji Multikolonieritas}

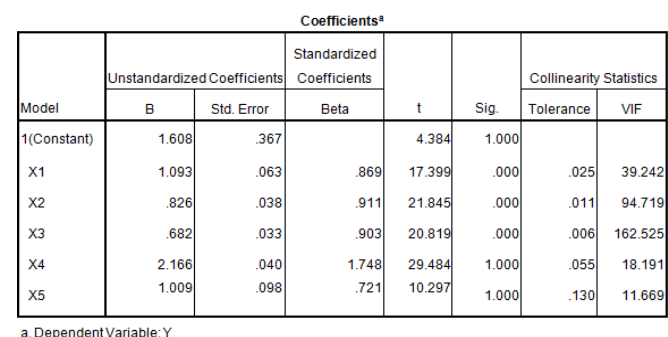

Jika nilai VIF > 10, maka terdapat multikolonieritas. Hasil VIF sebesar 39.242 untuk $\mathrm{X}_{1}$, hasil $\mathrm{X}_{2}$ sebesar $94.719, \quad \mathrm{X}_{3}$ sebesar $162.525, \mathrm{X}_{4}$ sebesar 18.191 dan hasil $\mathrm{X}_{5}$ sebesar 11.669. Dari hasil ke-lima variabel bebas (X) diatas > 10, sehingga disimpulkan bahwa terdapat multikolonieritas.

c. Uji Normalitas
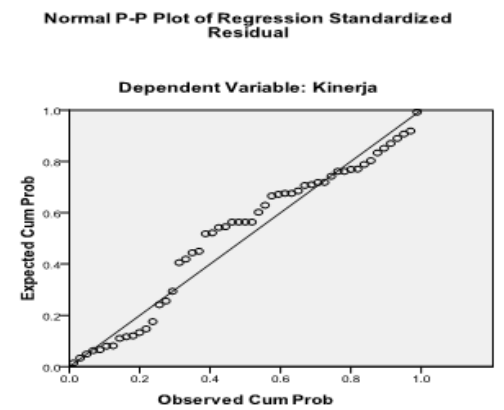

Sumber: Output SPSS 17.0

Pada gambar di atas dapat di lihat bahwa histogram dari residual dan grafik normal probability plot menunjukkan pola grafik yang normal. Hal ini terlihat dari titik yang menyebar disekitar garis diagonal dan penyebarannya mengikuti garis diagonal. Oleh karena itu dapat disimpulkan bahwa model regresi layak dipakai karena memenuhi asumsi normalitas.
Tabel 4. Regresi Linear Berganda

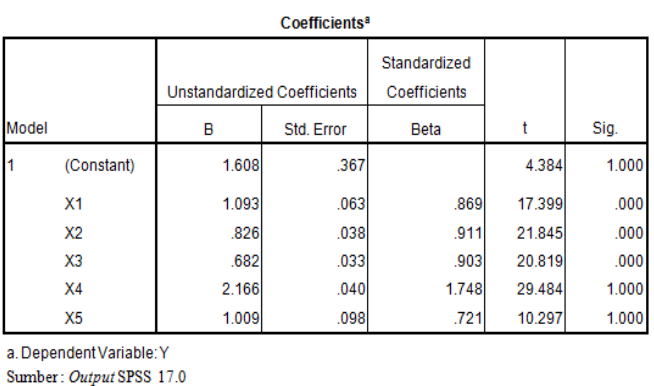

Pada tabel diatas, menunjukkan koefisien regresi linier masingmasing sebagai berikut:

a. Koefisien regresi kerjasama tim $\left(\mathrm{X}_{1}\right)$ sebesar 1,093 artinya jika kerjasama tim naik sebesar 1 satuan maka peningkatan laba akan meningkat sebesar 1,093.

b. Koefisien regresi perbaikan system secara berkesinambungan $\left(\mathrm{X}_{2}\right)$ sebesar 0,826 artinya jika kerjasama tim naik sebesar 1 satuan maka peningkatan laba akan meningkat sebesar 0,826 .

c. Koefisien regresi pendidikan dan pelatihan $\left(\mathrm{X}_{3}\right)$ sebesar 0,682 artinya jika kerjasama tim naik sebesar 1 satuan maka peningkatan laba akan meningkat sebesar 0,682 .

d. Koefisien regresi kesatuan tujuan $\left(\mathrm{X}_{4}\right)$ sebesar 2,166 artinya jika kerjasama tim naik sebesar 1 satuan maka peningkatan laba akan meningkat sebesar 2,166.

e. Koefisien regresi keterlibatan dan pemberdayaan karyawan $\left(\mathrm{X}_{5}\right)$ sebesar 1,009 artinya jika kerjasama tim naik sebesar 1 satuan maka peningkatan laba akan meningkat sebesar 1,009. 
Tabel 5. Korelasi Berganda

\begin{tabular}{|c|c|c|c|c|}
\hline \multicolumn{5}{|c|}{ Model Summary } \\
\hline Model & $\mathrm{R}$ & R Square & $\begin{array}{l}\text { Adjusted R } \\
\text { Square }\end{array}$ & $\begin{array}{c}\text { Std. Error of the } \\
\text { Estimate }\end{array}$ \\
\hline 1 & $.748^{\mathrm{a}}$ & .559 & .537 & 1.68510 \\
\hline
\end{tabular}

Nilai koefisien determinasi secara simultan sebesar 0,559. Hal ini menunjukkan bahwa fluktuasi (tingkat gerakan) nilai variabel terikat (Peningkatan Laba) yang disebabkan oleh variabel bebas yaitu Kerjasama Tim $\left(\mathrm{X}_{1}\right)$, Perbaikan Sistem Secara Berkesinambungan $\left(\mathrm{X}_{2}\right)$, Pendidikan dan Pelatihan $\left(\mathrm{X}_{3}\right)$, Kesatuan Tujuan $\left(\mathrm{X}_{4}\right)$, Keterlibatan dan Pemberdayaan Karyawan $\left(\mathrm{X}_{5}\right)$ sebesar 55,9\%. Sedangkan Peningkatan Laba di PT.Trijaya Cipta Makmur yang dipengaruhi oleh variabel selain Kerjasama Tim $\left(\mathrm{X}_{1}\right)$, Perbaikan Sistem Secara Berkesinambungan $\left(\mathrm{X}_{2}\right)$, Pendidikan dan Pelatihan $\left(\mathrm{X}_{3}\right)$, Kesatuan Tujuan $\left(\mathrm{X}_{4}\right)$, Keterlibatan dan Pemberdayaan Karyawan ( $\left.\mathrm{X}_{5}\right)$ adalah sebesar $44,1 \%$.

Berdasarkan Tabel 4 diperoleh hasil analisis uji t yaitu :

a. Variabel Kerjasama Tim $\left(\mathrm{X}_{1}\right)$

Hasil analisis uji $t$ diperoleh nilai $\mathrm{t}_{\text {Hitung }}$ sebesar 17,399, pada taraf signifikan $\alpha=0,05$, diperoleh nilai $\mathrm{t}_{\text {Tabel }}$ sebesar $1.661 \mathrm{df}=\mathrm{n}-\mathrm{k}$ $1(100-5-1=94)$, maka diperoleh asumsi $\mathrm{H}_{0}$ ditolak dan $\mathrm{H}_{\mathrm{a}}$ diterima, sehingga teruji variabel Kerjasama Tim $\left(\mathrm{X}_{1}\right)$ berpengaruh dan signifikan terhadap Peningkatan Laba (Y) pada PT.Trijaya Cipta Makmur. Hasil uji t diatas dapat dijelaskan dengan gambar sebagai berikut:

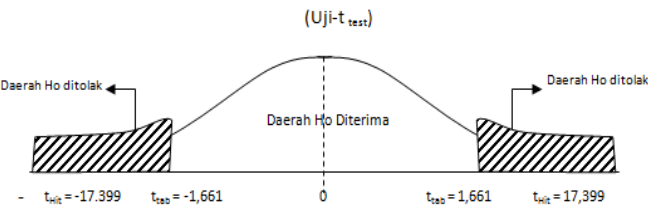

b. Variabel Perbaikan Sistem Secara Berkesinambungan $\left(\mathrm{X}_{2}\right)$ Hasil analisis uji t diperoleh nilai $t_{\text {Hitung sebesar } 21,845 \text {, pada taraf }}$ signifikan $\alpha=0,05$, diperoleh nilai $\mathrm{t}_{\text {Tabel }}$ sebesar $1.661 \mathrm{df}=\mathrm{n}-\mathrm{k}$ $1(100-5-1=94)$, maka diperoleh asumsi $\mathrm{H}_{0}$ ditolak dan $\mathrm{H}_{\mathrm{a}}$ diterima, sehingga teruji variabel Perbaikan Sistem Secara Berkesinambungan $\left(\mathrm{X}_{2}\right)$ berpengaruh dan signifikan terhadap Peningkatan Laba (Y) pada PT.Trijaya Cipta Makmur. Hasil uji t diatas dapat dijelaskan dengan gambar sebagai berikut:

c. Variabel Pendidikan dan Pelatihan $\left(\mathrm{X}_{3}\right)$

Hasil analisis uji t diperoleh nilai $t_{\text {Hitung sebesar 20,819, pada taraf }}$ signifikan $\alpha=0,05$, diperoleh nilai $\mathrm{t}_{\text {Tabel }}$ sebesar $1.661 \mathrm{df}=\mathrm{n}-\mathrm{k}-$ $1(100-5-1=94)$, maka diperoleh asumsi $\mathrm{H}_{0}$ ditolak dan $\mathrm{H}_{\mathrm{a}}$ diterima, sehingga teruji variabel Pendidikan dan Pelatihan $\left(\mathrm{X}_{3}\right)$ berpengaruh dan signifikan terhadap Peningkatan Laba (Y) pada PT.Trijaya Cipta Makmur. Hasil uji t diatas dapat dijelaskan dengan gambar sebagai berikut:

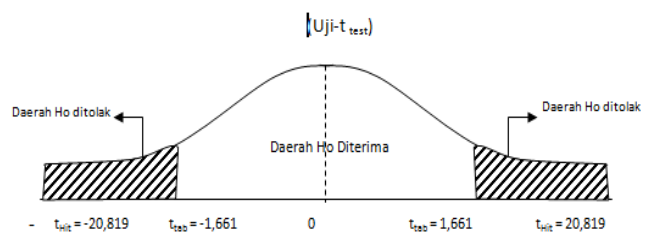

d. Variabel Kesatuan Tujuan $\left(\mathrm{X}_{4}\right)$ Hasil analisis uji $\mathrm{t}$ diperoleh nilai 


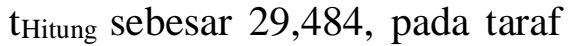
signifikan $\alpha=0,05$, diperoleh nilai $\mathrm{t}_{\text {Tabel }}$ Sebesar $1.661 \mathrm{df}=\mathrm{n}-\mathrm{k}$ $1(100-5-1=94)$, maka diperoleh asumsi $\mathrm{H}_{0}$ ditolak dan $\mathrm{H}_{\mathrm{a}}$ diterima, sehingga teruji variabel Kesatuan Tujuan $\left(\mathrm{X}_{4}\right)$ berpengaruh dan signifikan terhadap Peningkatan Laba (Y) pada PT.Trijaya Cipta Makmur. Hasil uji t diatas dapat dijelaskan dengan gambar sebagai berikut:

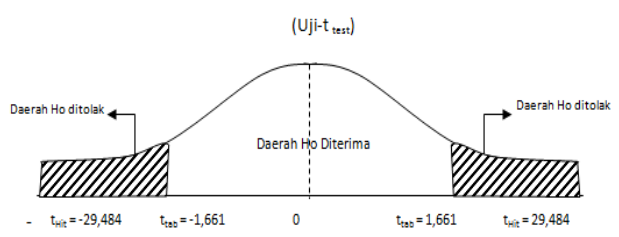

e. Variabel Keterlibatan dan Pemberdayaan Karyawan $\left(\mathrm{X}_{5}\right)$

Hasil analisis uji t diperoleh nilai $t_{\text {Hitung }}$ sebesar 10,297, pada taraf signifikan $\alpha=0,05$, diperoleh nilai $\mathrm{t}_{\text {Tabel }}$ Sebesar $1.661 \mathrm{df}=\mathrm{n}-\mathrm{k}-\mathrm{l}(100-5-$ 1 =94), maka diperoleh asumsi $\mathrm{H}_{0}$ ditolak dan $\mathrm{H}_{\mathrm{a}}$ diterima, sehingga teruji variabel Keterlibatan dan Pemberdayaan Karyawan $\left(\mathrm{X}_{5}\right)$ berpengaruh dan signifikan terhadap Peningkatan Laba (Y) pada PT.Trijaya Cipta Makmur. Hasil uji t diatas dapat dijelaskan dengan gambar sebagai berikut:

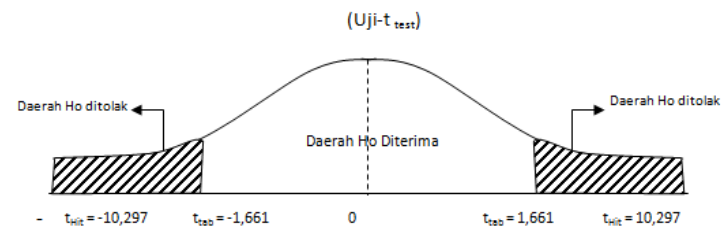

Tabel 6. Uji F

\begin{tabular}{|ll|r|r|r|c|c|}
\hline \multicolumn{1}{|l|}{ ANOVA $^{\text {D }}$} \\
\hline 1 & & Sum of Squares & Df & Mean Square & F & Sig. \\
\hline & Regression & 162.040 & 5 & 32.408 & 31.870 & $.000^{3}$ \\
Rosidual & 141.021 & 94 & 1.121 & & \\
Total & 162.040 & 99 & & & \\
\hline
\end{tabular}

a. Predictors: (Constant), X5, X2, X1, X4, X3

b. DependentVariable: $Y$

Sumber: Output SPSS 17.0
Uji $\mathrm{F}$ digunakan untuk menguji signifikasi pengaruh secara simultan antara variabel Kerjasama Tim $\left(\mathrm{X}_{1}\right)$, Perbaikan Sistem Secara Berkesinambungan $\left(\mathrm{X}_{2}\right)$, Pendidikan dan Pelatihan $\left(\mathrm{X}_{3}\right)$, Kesatuan Tujuan $\left(\mathrm{X}_{4}\right)$, Keterlibatan dan Pemberdayaan Karyawan $\left(\mathrm{X}_{5}\right), \quad$ terhadap Peningkatan Laba (Y) pada PT. Trijaya Cipta Makmur. Hasil analisis diperoleh $F_{\text {Hitung }}$ sebesar 31,870, sedangkan pada taraf signifikan $\alpha=$ 0,05 nilai $\mathrm{F}_{\text {Tabel }}$ sebesar 2,47 dengan Probabilitas (Sig.) sebesar 0,000 lebih kecil dari 0,05, maka diperoleh asumsi bahwa $\mathrm{H}_{0}$ ditolak dan $\mathrm{H}_{\mathrm{a}}$ diterima, sehingga teruji bahwa secara bersama-sama terdapat pengaruh yang signifikan antara variabel Kerjasama Tim $\left(X_{1}\right)$, Perbaikan Sistem Secara Berkesinambungan $\left(\mathrm{X}_{2}\right)$, Pendidikan dan Pelatihan $\left(\mathrm{X}_{3}\right)$, Kesatuan Tujuan $\left(\mathrm{X}_{4}\right)$, Keterlibatan dan Pemberdayaan Karyawan $\quad\left(\mathrm{X}_{5}\right), \quad$ terhadap Peningkatan Laba (Y). Hasil Uji F tersebut dapat dijelaskan dengan gambar berikut ini:

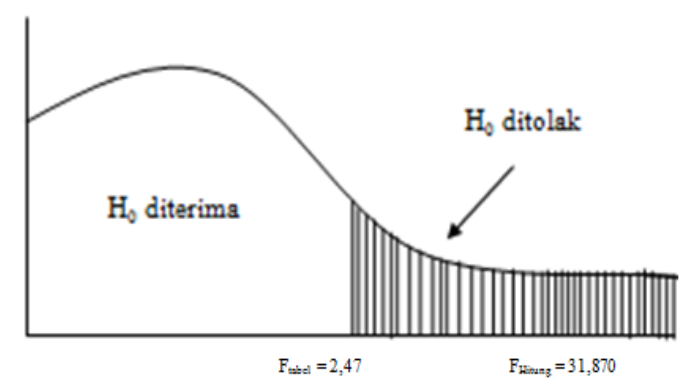

\section{KESIMPULAN DAN SARAN Kesimpulan}

Berdasarkan pembahasan di atas dapat disimpulkan bahwa Penerapan Total Quality Manajemen (TQM) berpengaruh signifikan secara parsial terhadap peningkatan laba pada "PT.Trijaya Cipta Makmur Lamongan". (2) Penerapan Total Quality Manajemen (TQM) 
berpengaruh signifikan secara simultan terhadap peningkatan laba pada "PT.Trijaya Cipta Makmur Lamongan". (3) Variabel kesatuan tujuan $\left(\mathrm{X}_{4}\right)$ yang berpengaruh paling dominan terhadap peningkatan laba pada "PT.Trijaya Cipta Makmur Lamongan" karena hasil $t_{\mathrm{Hit}}\left(\mathrm{X}_{4}\right)>$ ke-empat variabel lainnya.

\section{Saran}

Berdasarkan temuan-temuan tersebut maka diajukan saran untuk perusahaan diharapkan menerapkan Total Quality Manajemen secara efektif dan efisien agar nantinya peningkatan laba semakin meningkat dan mampu bersaing dengan perusahaan lain.

\section{DAFTAR PUSTAKA}

Gaspersz, Vincent. 2001. "Total

Quality Management". Jakarta:

PT Gramedia Pustaka Utama.

Harahap, Sofyan Syafri. 2011.

"Analisis Kritis Atas Laporan Keuangan". Jakarta: PT. Raja Grafindo Persada.

Rusdiana, 2014. "Manajemen

Operasi". Bandung : Pustaka

Setia.

Sugiyono, 2012. "Metode Penelitian

Kuantitatif Kualitatif dan

R\&D”. Bandung : Alfabeta. 